\title{
Lost in Translation
}

\section{How Street-Level Bureaucrats Condition Union Solidarity}

Thierry, Jessica Maria Sampson; Martinsen, Dorte Sindbjerg

Published in:

Journal of European Integration

DOI:

$10.1080 / 07036337.2018 .1509510$

Publication date:

2018

Document version

Peer reviewed version

Citation for published version (APA):

Thierry, J. M. S., \& Martinsen, D. S. (2018). Lost in Translation: How Street-Level Bureaucrats Condition Union

Solidarity. Journal of European Integration, 4O(6), 819-834. https://doi.org/10.1080/07036337.2018.1509510 


\title{
Lost in Translation: How Street-Level Bureaucrats Condition Union Solidarity
}

\author{
by \\ Jessica Sampson Thierry and Dorte Sindbjerg Martinsen \\ University of Copenhagen, Department of Political Science \\ Published in Journal of European Integration (2018), Vol. 40 (6): 819-834 \\ https://www.tandfonline.com/doi/full/10.1080/07036337.2018.1509510
}

\begin{abstract}
Translating complex, politicised and ambiguous European legislation and case law into practice is the difficult everyday condition for street-level bureaucrats in European Member States. Yet their crucial role remains remarkably understudied in EU compliance literature. This paper argues that 40street-level bureaucrats at local implementing levels in Europe are bound to manoeuver between what we define as respectively a European and a national legal logic in the patchwork of EU rules on free movement, equal treatment and cross-border social rights. The two legal logics are strikingly different, yet coexisting. Nonetheless, street-level bureaucrats are left without sufficient guidance in how to prioritise and administer the rules. Consequently, discretion of unclear, core concepts in European social law such as 'unreasonable burden', 'jobseeker' and 'worker' is decentralised, resulting in fragmented outcome on the ground. In the limbo between a European and national logic, Union solidarity, we find, gets lost in translation.
\end{abstract}

\section{KEYWORDS}

Europeanisation; EU implementation; Union Citizenship; street-level bureaucracy; court of justice of the EU; Union solidarity 


\section{Introduction}

Free movement of persons, the right to welfare across borders and equal treatment constitute a core part of the European social Union and form the nexus of Union solidarity. Over the last decades, the Court of Justice of the European Union (CJEU) has played a key role in further defining and contesting the scope and limits of the emerging social Union. An expansive practice of the Court, widening the social protection of mobile Europeans, is now claimed to be replaced by a restrictive trend, where social cross-border rights are limited (Dougan 2013). We argue that no matter the trend, two different, yet coexisting, legal logics emerge from this evolved patchwork of rules: respectively a European and national logic, representing respectively further European integration or protection of national welfare. They are strikingly different, leading to distinctively different outcomes, and yet they coexist in the same pool of applicable EU legislation and case law.

How this strand of complex legislation is translated into practice and how street-level bureaucrats in Member States prioritise between the two legal logics is essential for the materialisation of the social protection provided by EU social law. But the actual effect of these rules on national welfare states has only been examined to some extent and EU implementation studies have instead predominantly focused on national transposition of EU law (Mastenbroek 2003; Haverland and Romeijn 2007; Hartlapp 2009). The practical and local implementation of European social law has not caught much scholarly attention despite encouragement to do so (Versluis 2007; Thomann and Sager 2017; Mastenbroek 2006). Only very recent research provides a bottom-up approach to EU implementation and highlights the importance of local implementers' role in and individual motivation for turning EU law into a sometimes fragmented practice on ground (Dörrenbächer 2017). Others point out their role in actively containing the influence of the CJEU (Heindlmaier and Blauberger 2017). Despite their crucial role in turning EU law into 'action' (Versluis 2003), yet insufficient attention has been paid to the dispositions of street-level bureaucrats in effectuating the continuously changing rules and rights of Europe. This is where we aim to contribute.

This article takes us to this forefront of the European social Union. Ultimately, it considers how streetlevel bureaucrats function as crucial stakeholders when Court-driven rules are translated into practice on the ground. Recent literature has shown through an ethnographic legal method how Union solidarity is preserved for more privileged Union citizens while the rights of more vulnerable groups, conditioned by low-paid jobs, illness, parental leave and fixed-term contracts, are submerged by street-level bureaucrats in their practical implementation of CJEU jurisprudence (O'Brien 2017). This paper examines more specifically the importance of the dispositions of street-level bureaucrats in the practical administration of EU rules and rights. Focus is on how they manoeuver between the two different, yet coexisting, legal logics and how their behaviour may be shaped when EU law is unclear and potentially clashes with national provisions and political signals. The behaviour of street-level bureaucrats is crucial for the aim of this paper as well as the broader EU compliance literature as street-level bureaucrats make the everyday decisions on EU citizens' entitlements under EU law the actual outcome of EU rules. 
In concrete, we examine what influences street-level bureaucrats' decisions on homeless EU citizens' access to public shelters in the Member State of Denmark. Denmark constitutes a crucial case for examining the disposition of caseworkers when implementing EU law on the ground. Denmark is a unitary state with relatively high administrative capacity. Furthermore, a culture of 'law observance' with EU law is argued to guide political and administrative behaviour in Denmark (Falkner et al. 2007).

We examine street-level bureaucrats' dispositions upon the case of homeless EU citizens' access to public shelters in Denmark. What happens when the implementation of ambiguous and contested EU law concerns the rights of the poorest and presumably least-wanted group of mobile Europeans? This case serves to examine the scope of Union solidarity. It is furthermore well-suited for examining what influences the decisions of street-level bureaucrats as the ministerial interpretation of EU law on this matter changed in 2014, extending the social rights of EU citizens informed by a European rather than a national logic.

This paper engages with the downside of European free movement and how relevant EU legislation and case law fail to protect. 15.3 million Europeans resided in another EU Member State by the end of 2014. However, an unknown share experience comedown and need for shelter. Recent official counting of homeless in Denmark reports a remarkable increase in the number of foreign homeless migrants of which EU nationals constitute the large majority. Only three European individuals, however, were registered in public shelters. The use of private shelters is significantly more frequent among Union citizens than among homeless Danes, indicating that EU citizens have a considerable demand for shelter but avoid public offers (interviews 2015 PSMM3, PSMM5).

We examine the decisions of street-level bureaucrats upon rich empirical research going into depth with practices on the ground in the final implementing phase. This is where supranational rules and rights are turned into practice. We have conducted 23 semi-structured interviews with a total of 27 key respondents between August 2015 and June 2017 in respectively the central and local executive level as well as among street-level bureaucrats themselves and private shelter mangers (all anonymised according to title of respectively civil servant, street-level bureaucrat or private shelter manager, i.e. CS, SLB or PSM). Interviews are triangulated with available data, official and unofficial documents. The respondents at central level represent the Ministry of Social Affairs, The Danish Agency for Labour Market and Recruitment, Danish Immigration Service and the State Administration. The local level is represented by five case municipalities (anonymised as M1, M2, M3, M4 and M5), selected primarily upon having EU residents and representing the biggest Danish cities and secondly upon variation in overall population size, political leadership and geography. The interviewed street-level bureaucrats are shelter managers from public shelters in each of the five municipalities, providing insights into the final level of implementation of this EU law and how it is turned into practice.

The paper is structured as follows. We first present the theoretical framework for examining the role of street-level bureaucrats in the EU implementation process. We then introduce EU rules and show how they are informed by respectively European and national logics. Three analytical parts examine 
the practical implementation of transforming these rules into rights. In conclusion, we reflect upon how our findings correspond with our theoretical expectations.

\section{Frontline implementation of EU law}

Studies of EU compliance have foremost focused on judicial implementation of directives, aiming to explain variation in Member States' transposition performance. However, after transposition comes practical implementation. Versluis' study of 'EU law in action' points out that although EU law may be transposed correctly and completely, it can still have limited effect on ground (2007). The numerous studies of legal implementation are found to be narrow in perspective and insufficient to understand and explain the subsequent steps of applying EU law (Versluis 2007, 50). We argue that implementation literature originally derived from the studies of federal states, provides a useful theoretical and conceptual platform for exploring the effectuation of EU law further. Implementation research tells us that street-level bureaucrats' behaviour, capacity and attention are crucial to policy outputs and outcomes (Lipsky, 2010 [1980]) as they make 'important discretionary decisions' for the target groups of implementation (Winter 2012,260). The theoretical puzzle in focus in this paper thus becomes what influences such behaviour.

As in classical implementation research, EU implementation as a concept covers how objectives, rights and obligations of EU law are carried out, accomplished, fulfilled, produced or completed (see Pressman and Wildavsky 1973, xxi). To examine the effectuation of EU law, we argue that an 'integrated' implementation perspective is needed. The model centres around the most important explaining variables that research of national implementation has identified to condition implementation results (Winter 2012, 257ff). Outcomes of policy objectives constitute the dependent variable, which in our case is defined as EU citizens' access to public shelters.

According to the integrated implementation model, organizational and inter-organizational behaviour are factors likely to condition outcomes. This resembles the insights in an EU setting gained from transposition studies. Conflicts between national coalition partners, between ministries, boards and agencies are likely to impair the quality of judicial implementation. Contrarily, administrative capacity and inter-ministerial coordination is held to positively impact on implementation performance (Haverland and Romeijn 2007; Mastenbroek 2003). This points to the importance of how different executive levels interact in order to implement EU law. For our case, we expect the interaction and agreement between different executive levels to influence the dispositions of streetlevel bureaucrats.

The integrated implementation model then informs us that policy formulation and policy design condition which outcome is produced. They both shape implementation and dispositions of streetlevel bureaucrats (May 2012). Conflicts from the policy for- mulation phase may lead to a policy design with ambiguous objectives and mixed or ineffective instruments. Such unresolved conflicts will continue into the implementation phase (Bardach 1977). In addition, the individual attitude of the caseworker is likely to impact on his/her decisions (Dörrenbächer 2017). In other words, the 
policy-making process and thus policy design matters to implementation as it carries forward conflicts, ambiguity, discretion and salience. Applied to our case, we expect the clarity of EU rules and how they are reflected in the Danish policy to influence the dispositions of street-level bureaucrats.

Furthermore, politicians can influence street-level behaviour by the laws they adopt, the instruments they assign to meet their policy goals but also by their 'signals', i.e. the importance and priority they communicate to a policy. The extent to which politicians take ownership for a policy and communicate the political goals clearly is likely to matter in how the policy is implemented in the frontlines. Political attention signals to street- level bureaucrats that what they do on the ground is noticed (Winter and May 2007, 456). Hereto comes managerial influence, which concerns the extent to which administrative superiors signal the importance of a policy. In concrete, this may be done when higher-level civil servants supervise and monitor frontline decisions. Management of practices is no easy task as street-level bureaucrats normally enjoy considerable discretion. On the other hand, supervision, clearly communicated goals and expectation may limit such discretion and diminish the policy divergences between political objectives, management and the frontlines of implementation (Winter and May 2007). However, for political and managerial signalling to matter the most, it needs to be performed in agreement. If local politicians signal their disagreement with national politicians, street-level bureaucrats are likely to be influenced.

Applied to our case, formulating our third and last theoretical expectation, we expect political and managerial signalling to influence the dispositions of street-level bureaucrats.

\section{EU rules: European and national logic}

One of the most substantive achievements of the European social Union is the right for European citizens to move to another Member State, become member of that Member State's welfare community and there enjoy the right to equal treatment. However, at the same time EU and national law detail and condition the scope and limits of these rules and rights. We show that from this patchwork of rules and rights, two different legal logics emerge and may inform street-level bureaucrats when granting access to shelters.

The first path rests upon a European logic, steered by the aspiration after further European integration. This is reflected in the establishment of Union Citizenship in the Maastricht Treaty signed in 1992 and the right to move and reside freely within the Union, now enshrined in the Treaty provisions of Article 20(1), 20 (2a) and 21(1) TFEU. The second path rests upon a national logic, derived from secondary legislation, primarily Directive 2004/38. In Denmark, the Directive is transposed among others by way of a legal act ('Udlændingeloven') ${ }^{1}$ andministerial order ('EUholdsbekendtgørelsen'). ${ }^{2}$

This European logic is steered by a wish to protect Member State interests and national welfare. According to this logic, status as a 'worker' becomes the gateway of entrance into the national welfare system. Worker status depends on contributions to the hosting Member State in the form 
of work prior to being included in the national solidarity sphere. The status can be retained temporarily under certain conditions in the case of involuntary unemployment. Safeguards have been inserted in the Directive 2004/38 requiring that the person must not become an 'unreasonable burden' upon the social assistance system of a hosting member state (Art. 14(1)). Both paths can be deferred from the patchwork of EU regulation and case law but vary in conditions demanded of the mobile European, resting upon respectively a low and higher bar of inclusion. The Court has played a tremendous role within both paths in defining the personal and material scope of and limits to crossborder welfare regulation, interpreting who should have rights to which types of social benefits (Dougan 2013). Firstly, we elaborate on how the Court has expanded social rights.

Most remarkably, the Sala case in 1998 (C-85/96) initiated a judicial vision of Union Citizenship as a fundamental status of Member State nationals (Dougan 2013, 133). Grzelczyk (C-184/99), established also in case law the right to move and reside freely as a result of rejecting discrimination upon nationality no matter worker status (para 29 and 31). Here, the Court also clarified that despite the safeguards introduced to protect against 'unreasonable burden[s]', Member States are expected to accept 'a certain degree of financial solidarity' (para 44). Baumbast (C-413/99) granted equal treatment and access to the welfare schemes of a hosting Member State also for economically inactive Union citizens. Brey (C-140/12) ruled against the automatic exclusion of Union citizens from benefits in another hosting Member State and required an individual assessment of personal circumstances such as duration of residence, amount of income, amount and duration of benefits claimed. Both the Baumbast and Brey cases are pivotal for establishing the fundamental status of Union Citizenship also for economically inactive EU citizens.

The expansive phase of the Court described above is argued to have turned into a more reactionary phase - in our terms a national logic - across the three core features of free movement of persons, the right to cross-border welfare and equal treatment (O'Brien 2016; Shuibhne, 2015). In the Förster (C-158/07) and Vatsouras (C-23/08) cases, the Court examines the more restrictive formulations of secondary law, as defined in Directive 2004/38, derogating from Union citizens' general right to equal treatment (Dougan 2013, 140). The more restrictive judicial approach has become even more notable in the recent case law of Dano (C-333/13), Alimanovic (C-67/14) and García- Nieto (C299/14). All state clearly the necessity of a link to the host Member State in order to fully access social assistance. As Jacqueson concludes; ' [w] ork is more or less the sole gateway for Union citizens to access social rights' (7 July 2016, http://beucitizen.eu/ back-to-business-the-court-in-alimanovic/).

Two complex and at times contradictory logics coexist in the EU regulation on free movement, equal treatment and subsequent social rights. Their coexistence creates room for manoeuvre for the local administrations and caseworkers and their potential conflict is expected to inform all three expectations as a silent, yet crucial background variable. Firstly, it may complicate the interaction and agreement between different executive levels when two different logics are at play, vis-à-vis the first expectation. Secondly, it may obviously make the EU rules more difficult to interpret and result in lack of clarity, vis-à-vis the second expectation. Thirdly, it may make street-level bureaucrats more vulnerable to political and managerial signalling, vis-à-vis the third expectation. We now 
turn to examine exactly this through our three theoretical expectations concerning what conditions the dispositions of street-level bureaucrats when Union citizens ask for shelter.

\section{Interaction between executive levels}

In the wake of the Central and Eastern European enlargement in 2007, the former Danish Minister for Welfare from the liberal party Venstre stated that 'Denmark should not become the shelter for all European citizens' (Politiken, 22 December 2007). As a direct consequence, Danish shelters were instructed to deny access to homeless Union citizens. In 2011, a Social Democratic coalition government took office and for three years, it maintained the position of the former government. However, in December 2014, the government changed position with reference to Directive 2004/38. As a result, new guidelines were produced, now instructing public shelters to welcome homeless EU nationals under certain conditions. We identify this change in policy December 2014 as a movement from a national logic to a more European logic. This change is rather remarkable seen in the context of the CJEU's turnaround claimed to have undergone the opposite change from an expansive to a more restrictive path. The argumentation in the new Ministry guidelines prove strikingly European and reflects a high level of solidarity. Worker status is not a precondition for access, as would be the case if national logic dominated, and apart from belonging to the target group,3 only two conditions are required; 1) lawful residence according to the Directive and 2), that the EU national will not become an 'unreasonable burden' when being allowed access to the shelters.

The guidelines were produced in collaboration between the Ministry of Social Affairs and the Ministry of Justice (interview 2017 CSMinistry). Whereas the Ministry of Social Affairs only required that the person should belong to the target group and have lawful residence, the Ministry of Justice inferred the condition on 'unreasonable burden'. The inter-ministerial coordination was sparse in this process. Without further collaboration, the Ministries simply wrote one page each, defining respectively how to open up versus how to restrict access. The confusion at local and street-level, identified beneath, on how to balance access to public shelters with the assessment of 'unreasonable burden' begins here (interview 2017 CSMinistry). This suggests the importance of horizontal, interministerial coordination for the dispositions of street-level bureaucrats in carrying out a policy.

An email notifying about the new guidelines was sent from the Ministry to all 98 municipalities' main inboxes (interview 2017 CSMinistry). Despite this sparse circulation, all five case municipalities have somehow heard of the new guidelines (interviews 2015 CSM1-M5). There was no circulation from the municipalities, besides one (M3), down the administrative ladder to the shelters. As a shelter manager states, 'This might sound crazy, but I found the Ministry guidelines on Facebook, not via the municipality' (inter- view 2015 SLBM4). This suggests beyond the theoretical expectation that not only horizontal coordination matters, but also vertical, in this case (inadequate) downward, dissemination from the Ministry to the frontline influences the dispositions of the street- level bureaucrats.

Shortly after circulating the new guidelines, the Ministry invited a small group of the 98 Danish municipalities to an orientation meeting (interviews 2015 CSM2-M3, CSM5). This resulted in the 
production of municipal guidelines in two of our case municipalities (interviews 2015 CSM3, SLBM5). In one of them, the local guidelines, however, were not disseminated among shelter managers who should carry out the policy. Moreover, the local guidelines directly dispute the Ministry and deny access to job-seeking EU nationals (interviews 2015 CSM3, SLBM3). They contradict the European logic of the ministerial guidelines and suggest incomplete communication and control between the administrative levels. Furthermore, they reproduce the opinion of the association and interest organisation of Danish municipalities (Kommunernes landsforening, LGDK) who follow a national logic and - with an indisputable economic incentive4 - argue that residing at a shelter per se constitutes an unreasonable burden for the social system. The automatic rejection of EU nationals suggested here breaches with the Brey ruling and the discretion required in the Ministry guidelines as the potential burden on the social system is required to be assessed individually. Thus, even when made, municipal guidelines do not necessarily further the understanding of how to administer the new rules. The target group themselves are only poorly informed about their expanded rights and expect to be denied access to public shelters (interviews 2015 PSMM3 and PSMM5). Municipalities and shelter managers are puzzled by the limited number of inquiries from EU nationals (interviews 2015 SLBM2-M3, SLBM5). 'It is almost a non-existing phenomenon,' a civil servant states (interview 2015 CSM1). Meantime, inquiries at private shelters boom with around 250 per month (interviews 2015 PSMM3, PSMM5). The perception among EU nationals of continuously closed doors pushes the homeless from public shelters to private options. Private shelters provide basic help and shelter on a day-to-day basis, but no extensive socio-educational assistance or continuous guarantee of support. Instead, they are forced on a daily basis to refuse inquires because of lack of capacity (interviews 2015 PSMM3, PSMM5).

In acknowledging the lack of more hands-on municipal guidelines, the Ministry has now planned to produce a new set of guidelines to the municipalities that could meet the demands of defining central concepts and providing more specifications on when to allow or reject EU nationals (interview 2017 CSMinistry). So far, however, continuous political salience of EU nationals' access to Danish welfare discourages the Ministry from taking action (interview 2017 CSMinistry). Legal uncertainty is the preferred option when the rules are controversial.

Inadequate vertical communication across the different administrative levels results not only in fragmented dissemination of the guidelines but moreover in highly varied interpretations and compliance. Three of the five case municipalities (M1, M2 and M5) administer against the ministerial guidelines and deny access to EU nationals (interviews 2015 CSM1-M2, CSM5). Here, one municipality does not perceive the guidelines to lead to legal change: 'At first, we thought that this would change our legal guidelines, but actually there was nothing new here. If an EU national knocks on our door totally shabby, of course he will be let in but only for a night or two' (interview 2015, CSM1). The level of protection provided here does not go beyond basic acute support. Another municipality (M2) officially welcomes the new guidelines but has refrained from changing practice. The civil servant disagrees with the European logic in the Ministry guide- lines and refuses to expand the level of solidarity beyond own citizens (interview 2015 CSM2). 
Two municipalities on the other hand allow access to Union citizens. In stark contrast with the argumentation above, one perceives the guidelines not only as a simple orientation but as an actual legal change (interview 2015 CSM3). As a result, practices are changed both at municipal executive level and among shelter managers. The other municipality allowing access did so also before the Ministry guidelines supporting a European logic both before and after the change in ministerial guidelines (interviews 2015, CSM4, SLBM4).

Interviews with shelter mangers reveal, however, that compliance with the municipal line on ground should not be taken for granted. Instead, shelter managers in the two denying municipalities (M1 and M5) dissent from the municipal line and allow access to EU nationals. 'We, act on the basis of our charitable values and do not take residence permit or nationality into account' (interview 2015 SLBM1) resisting the national logic and clear managerial signalling from the executive level described beneath. Equally, the other shelter manager only requires lawful residence and refuses to assess potential unreasonable burden because helping people in need is their raison d'être irrespective of expenses. The behaviour of both shelter managers stresses the importance of the discretion made by street-level actors. Both make important and independent discretionary decisions even in one case despite strong managerial signalling. They also reflect, as Dörrenbächer has pointed out, that the individual attitude of the caseworker is likely to impact on his decisions (2017).

In sum, practices are fragmented both across and within municipalities as summarised below (Figure $1)$. 
FIGURE 1 Practices and Compliance across Levels 


\begin{tabular}{|c|c|c|c|}
\hline & $\begin{array}{l}\text { LEVEL } \\
\end{array}$ & PRACTICES & COMPLIANCE \\
\hline \multirow{2}{*}{ M1 } & Executive & Denying access & Non-compliance \\
\hline & Frontline & Allowing access & Compliance \\
\hline \multirow[t]{2}{*}{ M2 } & Executive & $\begin{array}{l}\text { De facto denying } \\
\text { access: Officially } \\
\text { welcomes the new } \\
\text { guidelines but has } \\
\text { signalled to the shelter } \\
\text { to deny access } \\
\end{array}$ & Non-compliance \\
\hline & Frontline & Denying access & Non-compliance \\
\hline \multirow{2}{*}{ M3 } & Executive & Allowing access & Compliance \\
\hline & Frontline & Allowing access & Compliance \\
\hline \multirow{2}{*}{ M4 } & Executive & Allowing access & Compliance \\
\hline & Frontline & Allowing access & Compliance \\
\hline \multirow{5}{*}{ M5 } & Executive & Denying access & Non-compliance \\
\hline & Frontline & Allowing access & Compliance \\
\hline & Frontline & $\begin{array}{l}\text { De facto denying } \\
\text { access: Only allows } \\
\text { access if the Union } \\
\text { citizen has residence } \\
\text { in another } \\
\text { municipality and that } \\
\text { their payment is } \\
\text { guaranteed }\end{array}$ & Non-compliance \\
\hline & Frontline & $\begin{array}{l}\text { De facto denying } \\
\text { access: Only allows } \\
\text { access if the Union } \\
\text { citizen has residence } \\
\text { in another } \\
\text { municipality and that } \\
\text { their payment is } \\
\text { guaranteed }\end{array}$ & Non-compliance \\
\hline & Frontline & Denying access & Non-compliance \\
\hline
\end{tabular}

New legal guidelines from the Ministry, intended to change practice into compliance with EU law, have been implemented in a highly fragmented manner. We confirm our first theoretical expectation and identify how dispositions of the street-level bureaucrats are informed by interaction and agreements between ministries, the executive levels at national and local levels. Beyond our theoretical expectation, we also identify that vertical, downward collaboration between the executive 
level and street-level bureau- crats inform their dispositions leaving them without sufficient knowledge of how to turn EU law into practice.

\section{Clarity of EU rules}

Clarity of EU rules has shown to condition the disposition of shelter managers in three different ways. It is widely perceived that problems in practice primarily emerge because central but unclear legal concepts and conditions are left open for interpretation at the frontline (interviews 2015 SLBM1M5). 'Lawful residence', as an example, is a precondition for eligibility for shelters but relies upon complex legal assessment. Firstly, application of social protection might for first-time jobseekers conflict with the grounds on which residence permit was granted in the first place; applying for shelter can, for example, disturb the impression of economic self-sufficiency. Secondly, first-time jobseekers have lawful residence for at least the first six months' residence but are not required to register upon arrival nor can they be imposed to document date of arrival. This creates an obvious barrier for assessing the duration of residence.

Moreover, first-time job-seekers are not in Danish administration in general perceived eligible to social welfare (interviews 2015 CSDanish Immigration Service; 2015 and 2017 CSState Department). This practice reflects a national logic where status as worker is the typical precondition for social protection. The ministerial guidelines, however, express a European logic where Union citizens should be considered access and recourse to the social system should not automatically lead to an expulsion measure (Directive 2004/38, Art. 14 (3)). The risk of constituting an unreasonable burden, it is argued, should instead rely upon a 'concrete assessment' where duration of residence, 'personal circumstances' and job search should be taken into account (cf, Brey, interview 2015 CSState Department). Without further guidance, this collision of arguments leaves shelter managers in the limbo between the European and national logic.

The assessment becomes even more complex, when the EU applicant might have obtained worker status and is more 'deserving' according to a national logic. Here, the shelter manager is required to consider what qualifies as actual employment, something the Court has struggled defining throughout many decades. Furthermore, the shelter manager shall differentiate between EU migrants who have worked in Denmark for respectively less and more than 12 months (interview 2015 CSState Department, cf. Directive 2004/38 Article 7(3), cf. Alimanovic). Less than 12 months suggests a right to 6 months' social welfare, whereas longer employments allow for social welfare as long as one looks for work in a genuine and effective way (interviews 2015 CSState Department, CSDanish Immigration Service).

The assessment of what constitutes an unreasonable burden is complicated further as the rules and Court cases are defined upon receipt of social assistance, a benefit-in-cash significantly lower than the expenses associated with granting a benefit- in-kind as a shelter spot.5 The shelter managers are not guided in whether or how to take actual expenses into account. Consequently, some find it unreasonable to allow EU nationals access to shelters just for one night, whereas others treat them as 
Danes. In sum, the mere category of the Union citizen is defining for the access to shelter but the various categories are not defined in the Ministry guidelines. 'I cannot,' a shelter manger explains, 'find my way around all the different kinds of status that EU nationals can obtain' (interview 2015 SLBM2). 'How do you,' another shelter manager asks, 'define a job-seeker? Do you require documentation that the person has been bicycling about to pizzerias with his CV?' (interview 2015 SLBM3).

Our interviews revealed a second issue concerning the clarity of EU rules. The parallel application of 1), EU law on free movement and 2), Danish national legislation on public shelters results, it is argued, in a Catch 22 situation. Applying one is perceived to exclude the other. Retaining worker status obliges the EU migrant to look for work in a genuine way (Directive 2004/38 Art. 7(1)b and 14(4)). The guidelines require that EU nationals can provide documentation that they search for work and have 'real chances for employ ment'. However, respondents argue that looking for work in a genuine way excludes the person from being categorised as a homeless and eligible to shelter according to Danish social legislation (interviews 2015 CSM1, SLBM2, SLBM5). Here, homelessness is defined upon having social problems such as alcohol or drug addiction, psychiatric disorders or lack of social network either without a home or without ability to live in their home. 6 'In order to be homeless within this definition,' a municipality argues, 'one cannot also look for work in a genuine way - and vice versa. The two situations are mutually exclusive' (interview 2015 CSM1). The Catch 22 situation leaves it up to the shelter manager to manoeuver in this unclear discretionary space.

A third issue concerning the clarity of EU rules emerges as, even when trying, shelter managers are often withheld from further guidance. Insufficient knowledge pushes them into seeking legal advice at the municipal executive level. Here they, however, often express to be incapable of providing clarification, forcing shelter managers to make the decision without the required knowledge. As a shelter manager describes; 'but you are the one who is supposed to make the decision, he replies when I ask for advice' (interview 2015 SLBM5). Civil servants refer to shelter managers, as 'they know much more about the practices than we do' (interview 2015 CSM4). The lack of sufficient guidance between administrative levels decentralises the interpretation of complex EU law and leaves the shelter managers with a large discretionary space.

Several shelter managers disapprove of the degree of discretion that they are supposed to manage and feel insufficiently informed to master the rules (interviews 2015 SLBM2-M3, SLBM4-M5). 'In this way, I get more power than I wish to have,' (interview 2015SLBM4). As follows, discretion is tossed around the administrative system, unwanted by all levels but landing in the hands of streetlevel bureaucrats who are forced to decide despite insufficient qualifications. A legally binding administrative principle ruling was ruled just a few weeks before the publication of the new Ministry guidelines and established that decisions made by shelter managers cannot be appealed.7 This requires to an even larger degree that the decision is correct in the first place. The shelter manager becomes sovereign in his or her decisions - irrespective of wishing it or not. 
Legal uncertainty confuses how EU law should be transformed into practice. We see here how central concepts are left open for interpretation by the Union legislators and remain undefined by the competent Ministry. The implementation process thus carries ambiguities rooted in political conflicts at EU level down to shelter managers in the streets of Denmark. Not only horizontal but also inadequate vertical communication and collaboration inform the ability of the street-level bureaucrats to practice EU rules. Such decentralisation of discretion results in heterogeneous practices and uneven treatment of Union citizens' need for social protection across municipalities.

\section{Political and managerial signalling}

As a third parameter, also political and managerial signalling conditions the dispositions of streetlevel bureaucrats. When studying de facto implementation all the way to the ground, it becomes evident that EU legislation and the CJEU case law constitute distant opaque reference points whereas national legislation has clearer and more directly applicable effect. When practitioners are asked to handle both European law and national legislation, the choice falls upon the national legislation being the nearest and most clearly defined option. 'When I assess a citizen's rights,' a civil servant explains, 'I know in the background somewhere is EU law, but to be honest, I find it irrelevant. I am not competent to assess EU law and I do not expect that I am required to have knowledge about EU law in any way. I only consider what is incorporated into Danish legislation' (interview 2015 CSM2). European law recedes into the background with no prevalence other than if directly incorporated into Danish legislation. The mere act of circulating the new guidelines over email alone and not incorporating them as published legal guidelines in this way functions as managerial signalling in itself. The process reflects lack of ownership and the new guidelines are not, it signals, of high importance. The Ministry is perceived unwilling to provide concrete useful answers on the interpretation of the rules. 'Their answers are too vague and useless' (interview 2015 CSM2). The civil servant suggests that their vagueness is rooted in an attempt to evade a clear stance on a politically sensitive topic. The lack of communication also becomes managerial signalling in itself suggesting to ignore potential politically sensitive cases. As a result, the safe choice becomes to reject Union citizens.

Several shelter managers outlined the resistance towards the new guidelines by the association of Danish municipalities (LGDK) during our interviews. When asked whether to follow the EU and Ministry line or their interest organisation perspective, a shelter manager responded that the LGDK is 'in a way our overall employer. They are the ones we listen to' (interview 2015 SLBM3). Several others express similar national legal logic and articulate sympathy with the interest organisation's interpretation of the law. 'I am after all hired to serve my own municipal citizens - not Poles who just arrived' (interview 2015 CSM2). The shelter manager subsequently follows these instructions and rejects Union citizens because of the clear managerial signalling (interview 2015 SLBM2).

In contrast to the clear standpoint reflected in the former Ministry guidelines, the political signalling of the new instructions is close to non-existing. The only clear example of political signalling agitates against allowing Union citizens access and is expressed by the highest political leader in one of the 
biggest municipalities. 'We, in Denmark,' he states on the municipality website in direct confrontation with the Ministry, 'should be extremely aware that we do not take on all Europe's social and poverty issues in our eagerness to demonstrate our pan-European sentiment.' 'A spot at a shelter costs 1000 to 2400 DKR [133 to 320 Euro ed.] per day and it would be an unreasonable burden for the social system in Denmark if a person merely on the grounds of being a job-seeking EU national should have access to the shelters'.8 The political signalling is unmistakably clear here, reflecting a national logic where own citizens should be prioritised over other Europeans. The strong political signalling has gained ground and is followed in the frontline of this municipality where similar arguments are expressed.

The only political signalling from the Ministry comes in a form of indirect threat against making a faulty decision. Just prior to circulating the new guidelines, the Minister made it clear to the Danish Parliament that taking in unregistered Union citizens at shelters comes with the risk up to 2 years imprisonment, a rather unusual working condition for a street-level bureaucrat.9 This was again repeated at the orientation meeting in December 2014 (interviews 2015 SLBM3, CSDanish Immigration Service). A ripple of reactions apparently ran through the administrative system and left no doubt among shelter managers about the risks of taking in Union citizens.

Shelter managers are informed by weak managerial signalling combined with strong political signalling agitating respectively against the new guidelines or against making faulty decisions. Without a notion of ownership through guidance on central concepts, national law remains primacy over EU law. As a consequence, EU law is perceived opaque, irrelevant and distant from the everyday at the frontline.

\section{Conclusion}

The CJEU is argued to play a tremendous role for the expansion and subsequent restriction of social rights for Europeans who exercise their right to free movement in the Union. This paper argues that no matter the trends in the Court's rulings, EU compliance literature has overlooked the crucial role of street-level bureaucrats in turning EU law into actual material rights for Europeans on the move.

This paper shows that the EU regulation in this field forms two separate and contradictory, yet coexisting, legal logics, respectively a European and a national logic. The first expresses cross-border solidarity based upon Union Citizenship, reflected in expansive rulings such as Sala and Brey. The second, contrarily, expresses protection of national welfare based upon principles of earning access to national welfare through obtaining status as a worker. This logic is reflected in restrictive rulings such as Förster, Vatsouras, Dano and Alimanovic. Our paper finds that when such a complex set of rules is implemented on the ground, street-level bureaucrats administer in the limbo between the two logics without sufficient guidance from higher national administrative levels. Core legal concepts such as 'unreasonable burden', 'jobseeker' and 'worker' left undefined by the Union legislators and continuously unclear due to changing trends in the Court's jurisprudence remain undefined by national administration. In this way, implementation carries the ambiguities left behind by legislators, and discretion is decentralised with the result of a fragmented implementation on the ground. Streetlevel bureaucrats, we show, play a crucial yet so far understudied role in turning EU law into action. 
Compliance across levels shows to be a faraway idealistic ambition and a Europe in numerous administrative levels appears to come with correspondingly various practices.

New ministerial guidelines were supposed to widen Union solidarity and expand the social rights for homeless Union citizens in Denmark. We show that this attempt to change practice from resting upon a national to a European logic has only had limited effect. On these grounds, we conclude that streetlevel bureaucrats play a remarkable role for the actual outcome of Europeanisation. Given their understudied yet crucial role in implementing EU law, we have examined three theoretical expectations on what influences their dispositions when carrying out these rules. Interaction between executive levels, especially inadequate inter-ministerial coordination has made the Ministry guidelines ambiguous and difficult to translate into a homogenous practice. Sparse horizontal coordination hampers both the interpretation and dissemination of the new guidelines. We also found that clarity of EU rules plays a remarkable role in the transformation of EU law in action. Street-level bureaucrats find themselves left with more discretion than they can manage and are forced to make decisions without further guidance on undefined key concepts, such as 'unreasonable burden' and 'jobseeker' and 'worker'. Uncertainty of and contestation concerning the interpretation have made the Ministry and municipal executive levels leave them undefined and push the discretion down in the hands of shelter managers. Ambiguity travels with the implementation process, we conclude.

Thirdly, vague managerial signalling hampers ownership and prioritisation of the new ministerial guidelines. Strong political signalling on the other hand agitates for non- compliance. Overall, this case confirms our expectations that the dispositions of street- level bureaucrats play a crucial, yet overlooked, role in the practical implementation of EU law.

The concurrent existence of the two different logics have in conclusion made inter- action more difficult, EU rules appear more unclear and made street-level bureaucrats more vulnerable to political signalling. This has altogether weakened their dispositions to administer European free movement. Besides the theoretical expectations, we further- more discovered that primacy of national law and local preferences over EU law forms a central implementation barrier. EU law has direct effect and supremacy, as established with respectively Van Gend (C-26-62) and Costa vs Enel (C-6-64), but we identify another reality on the ground. Without clear EU rules or national guidelines, the implementation behaviour of street-level bureaucrats ultimately defines the outcomes of EU law. EU law recedes into the background while national and local interpretations and agendas rule in practice. This may be less of a problem when EU rules derive from Directives that will be transposed into national law. This did not, however, protect homeless Union citizens as their derived access to public shelters was left uncommented during the transposition phase (cf. 'EUOpholdsbekendtgørelsen'). This group remains on the margins of society and somewhat left between borders. A so far understudied and wider problem, how- ever, may arise from this when the EU rules are based on the Treaty, Court-driven or ensured by Regulations, as such legal structures depend crucially on the dispositions of local implementers in administrating in accordance with EU law. Especially here, their role becomes crucial for the protection of the law and mobile Europeans' legal rights. Moreover, it is noteworthy that the national logic is primarily founded in secondary legislation and thus more easily overcomes this problem whereas the European logic predominantly is pushed 
forward by Treaty provisions and the Court rulings, which presumably come with a higher risk of being compromised in the practical implementation.

Secondly, we show that not only horizontal but also insufficient vertical interaction across all administrative levels plays a remarkable role for the final outcome. Not only inter-organizational conditions should be taken into account when considering EU implementation, but also communication and cooperation across administrative levels. This might especially count for governance in a highly multilevel setting like this where complex EU rules defined in Brussels and Luxembourg are transformed into material social rights in the streets of Member States.

Without improved cooperation across administrative levels, comprehensible interpretation of legal concepts as well as clear political and managerial signalling, discretion is pushed downward and decentralised to street-level bureaucrats in the frontlines who are left without sufficient knowledge or guidance. Here, the specific scope of Union solidarity is instead informed by local agendas and streetlevel agency. New EU decision- making or jurisprudence may come to further clarify the scope of Union solidarity and how to manoeuver between the European and national logic but will be redundant without further Europeanisation of the local administration and street-level bureaucrats. Without Europeanisation of the local and frontline levels, Union solidarity gets lost in translation.

\section{Notes}

1. LBK nr 1117 af 02/10/2017.

2. BEK nr 474 af 12/05/2011.

3. LBK nr 988 af 17/08/2017 art. 110.

4. The municipalities bear half of the expenses (LBK nr 102 af 29/01/2018 art. 177 (1) number 5).

5. Social assistance: 930-1450 euro per month. Residence at a homeless shelter: $6000-12,800$ euro per month.

6. VEJ nr 14 af 15/02/2011 art. 171.

7. Principle ruling 60-14 KEN nr 9900 af 14/11/2014.

8. Municipality of Aarhus, 12 May 2014, 'Socialrådmand: Danske forsorgshjem er ikke for arbejdsløse EU-borgere' https://www.aarhus.dk/da/omkommunen/nyheder/2014/Maj/ Danskeforsorgshjem.aspx, our italics.

9. SOU Alm.del endeligt svar på spørgsmål 23, sagsnr. 2014-10,095. 


\section{REFERENCES}

Bardach, E. 1977. The implementation game: What happens after a bill becomes a law (1. ed.). Cambridge, Mass: MIT Press.

Dörrenbächer, N. 2017. "Europe at the Frontline: Analysing Street-Level Motivations for the Use of European Union Migration Law.” Journal of European Public Policy 24 (9): 1328-1347. doi:10.1080/13501763.2017.1314535.

Dougan, M. 2013. "The Bubble that Burst: Exploring the Legitimacy of the Case Law on the Free Movement of Union Citizens." In Judging Europe's Judges. The Legitimacy of the Case Law of the European Court of Justice, edited by M. Adams, H. de Waele, and J. Meeusen, 127-154. Oxford: Hart Publishing.

Falkner, G., M. Hartlapp, and O. Treib. 2007. "Worlds of Compliance: Why Leading Approaches to European Union Implementation are only 'Sometimes-true Theories'." European Journal of Political Research 46 (3): 395-416. doi:10.1111/ejpr.2007.46.issue-3.

Hartlapp, M. 2009. "Implementation of EU Social Policy Directives in Belgium: What Matters in Domestic Politics?" Journal of European Integration 31 (4): 467-488. doi: 10.1080/07036330902920051.

Haverland, M., and M. Romeijn. 2007. "Do member states make European policies work? Analysing the EU transposition deficit." Public Administration 85 (3): 757-778. doi:10.1111/j.1467-9299. 2007.00670.x.

Heindlmaier, A., and M. Blauberger. 2017. "Enter at Your Own Risk: Free Movement of EU Citizens in Practice." West European Politics 40 (6): 1198-1217. doi: 10.1080/01402382.2017.1294383.

Lipsky, M. 2010 [1980]. Street-level bureaucracy, 30th ann. Ed.: dilemmas of the individual in public service. New York: Russell Sage Foundation.

Mastenbroek, E. 2003. "Surviving the Deadline the Transposition of EU Directives in the Netherlands." European Union Politics 4 (4): 371-395. doi:10.1177/146511650344001.

Mastenbroek, E. 2006. “EU Compliance: Still a 'Black Hole'?” Journal of European Public Policy 12 (6): 1103-1120. doi:10.1080/13501760500270869.

O’Brien, C. R. 2016. "Civis Capitalist Sum: Class as the New Guiding Principle of EU Free Movement Rights." Common Market Law Review 53 (4): 937-977.

O'Brien, C. 2017. Unity in Adversity: EU Citizenship Social Justice, and the Cautionary Tale of the $U K$.

Modern studies in European law.

Pressman, J. L., and A. B. Wildavsky. 1973. Implementation: How Great Expectations in Washington are Dashed in Oakland; Or, why It's Amazing that Federal Programs Work at All (third ed.). University of California Press.

Shuibhne, N. N. 2015. "Limits Rising, Duties Ascending: The Changing Legal Shape of Union Citizenship." Common Market Law Review 52 (4): 889-937.

Thomann, E., and F. Sager. 2017. "Toward a Better Understanding of Implementation Performance in the EU Multilevel System.” Journal of European Public Policy 24 (9): 1385-1407. doi:10.1080/ 13501763.2017.1314542. 
Versluis, E. 2003. "Enforcement Matters. Enforcement and Compliance of European Directives in Four Member States.” PhD diss., Utrecht University.

Versluis, E. 2007. "Even Rules, Uneven Practices: Opening the 'Black Box'of EU Law in Action." West European Politics 30 (1): 50-67. doi:10.1080/01402380601019647. 